\title{
Remediation of polycyclic aromatic hydrocarbon (PAH) contaminated soil through composting with fresh organic wastes
}

\author{
Yuan Zhang • Yong-Guan Zhu • Sabine Houot • \\ Min Qiao • Naoise Nunan • Patricia Garnier
}

Received: 10 February 2011 /Accepted: 2 May 2011 /Published online: 17 May 2011

(C) Springer-Verlag 2011

\begin{abstract}
Introduction Composting may enhance bioremediation of PAH-contaminated soils by providing organic substrates that stimulate the growth of potential microbial degraders. However, the influence of added organic matter (OM) together with the microbial activities on the dissipation of PAHs has not yet been fully assessed.

Materials and methods An in-vessel composting-bioremediation experiment of a contaminated soil amended with fresh wastes was carried out. Four different experimental conditions were tested in triplicate during 60 days using laboratory-scale reactors: treatment S (100\% soil), W (100\% wastes), SW (soil/ waste mixture), and SWB (soil/waste mixture with inoculation of degrading microorganisms).

Results and discussion A dry mass loss of $35 \pm 5 \%$ was observed in treatments with organic wastes during composting in all the treatments except treatment $\mathrm{S}$. The dissipation of the 16
\end{abstract}

Responsible editor: Zhihong Xu

Y. Zhang $\cdot$ Y.-G. Zhu

Chinese Academy of Sciences, Institute of Urban Environment,

Xiamen, People's Republic of China

Y. Zhang $\cdot$ S. Houot $\cdot$ P. Garnier $(\bowtie)$

INRA-AgroParisTech,

UMR 1091 Environnement et Grandes Cultures,

Site de Grignon,

Thiverval-Grignon 78850, France

e-mail: pgarnier@grignon.inra.fr

N. Nunan

CNRS, UMR7618 -

Biogéochimie et Ecologie des Milieux Continentaux,

78850 Thiverval-Grignon, France

M. Qiao

Chinese Academy of Sciences,

Research Center for Eco-Environment Sciences,

Beijing, People's Republic of China
USEPA-listed PAHs was largely enhanced from no significant change to $50.5 \pm 14.8 \%$ (for SW) $/ 63.7 \pm 10.0 \%$ (for SWB). More obvious dissipation was observed when fresh wastes were added at the beginning of composting to the contaminated soil, without significant difference between the inoculated and non-inoculated treatments. Phospholipid fatty acid (PLFA) profiling showed that fungi and G-bacteria dominated at the beginning of experiment and were probably involved in PAH dissipation. Subsequently, greater relative abundances of $\mathrm{G}+$ bacteria were observed as PAH dissipation slowed down.

Conclusions The results suggest that improving the composting process with optimal organic compositions may be a feasible remediation strategy in PAH-contaminated soils through stimulation of active microbial populations.

Keywords Composting · Contaminated soil · PAHs . Bioremediation · Microbial communities · PLFAs

\section{Introduction}

Polycyclic aromatic hydrocarbons (PAHs) are one of the main contaminant classes in soils of former coal gasification sites, tar oil distillation plants, or wood-preserving industries (Wischmann and Steinhart 1997). Such highly polluted soils lead to ecotoxicological risks and have to be cleaned up. Various remediation, and in particular bioremediation procedures, are available (Alexander 1999; Wilson and Jones 1993). Since PAHs are hydrophobic compounds with low solubility in water, they have a great tendency to bind to organic matter or soil, limiting their availability to microorganisms (Volkering et al. 1992; Pignatello and Xing 1996; Carmichael et al. 1997; Zhang et al. 1998). The addition of organic materials can enhance biodegradation by improving soil texture and oxygen transfer and by providing energy sources to rapidly establish a 
large microbial population (Englert et al. 1993). Several studies have shown that the degradation of PAHs in contaminated soils is significantly higher after addition of compost (Kästner et al. 1994; Wischmann and Steinhart 1997). Kästner and Mahro (1996) found that adding compost enhanced the removal of soil-associated PAHs and suggested that the presence of microorganisms capable of degrading natural humic substances were responsible for the co-metabolic degradation of the PAHs. Moreover, microbial activity has been shown to form bound residues in soil-compost system (Kästner et al. 1999). PAH dissipation has been frequently observed during composting of various contaminated substrates including sewage sludge (Cai et al. 2007) and organic wastes (Brändli et al. 2005). The composting of contaminated soils has also been demonstrated to enhance the biodegradation of PAHs using both conventional windrow composting systems (Amir et al. 2005; Atagana 2004) and in-vessel composting systems (AntizarLadislao et al. 2006; Sasek et al. 2003). In-vessel composting techniques are easier to operate than conventional composting systems as temperature, moisture content, ventilation, etc. can all be controlled. Composting after addition of fresh green wastes would appear to be more efficient than the addition of mature compost for decreasing $\mathrm{PAH}$ concentrations in contaminated soil (Antizar-Ladislao et al. 2006).

In the field of bioremediation, most studies have applied final composting products, and these studies have established the fate of PAHs (Cai et al. 2007) and the effect of fungalbacterial culture on PAH degradation (Boonchan et al. 2000). However, few investigations have focused on the effect of fresh organic matter addition and microbial inoculation on PAH dissipation during composting of contaminated soil. Only a few reports have described the degradation of contaminants in soil after addition of complex organic materials such as composts (Sims et al. 1990). Research on biodegradation has demonstrated the potential of white-rot fungi to degrade PAH (Canet et al. 1999), and using the PLFA as a biomarker, it has been found that the Gramnegative bacteria are more sensitive to PAHs than Grampositive bacteria or fungi (Yang et al. 2007).

Therefore, our objective was to study how the addition of fresh waste mixtures might enhance $\mathrm{PAH}$ dissipation in a contaminated soil during composting in an in-vessel composting system and to identify the relationship between $\mathrm{PAH}$ dissipation and the evolution of organic matter characteristics, PAH retention, and changes in microbial community structure.

\section{Materials and methods}

\subsection{Experimental design}

Four experimental conditions were tested in triplicate during 60 days using laboratory-scale reactors. Treatments
S with $100 \%$ contaminated soil and W with $100 \%$ waste mixtures were considered as control treatments. In treatment SW, the contaminated soil was blended with the mixture of wastes (see below) with an optimal ratio of $0.8: 1$ (dry wt. soil/dry wt. wastes) (Antizar-Ladislao et al. 2005). The treatment SWB was similar to SW with the addition of two PAH-degrading microorganisms (Bacillus sp. and Fusarium sp.).

Treatments S (control), SW, and SWB aimed at studying the degradation of PAHs in the soil during the composting process. The three treatments were conducted with the same amounts of soil. The treatment $\mathrm{W}$ was used to study the decomposition of waste organic matter (OM) during composting.

\subsection{Contaminated soil}

The contaminated soil was collected from a site located in Beijing $\left(39.85^{\circ} \mathrm{N}, 116.54^{\circ} \mathrm{E}\right)$ which was highly polluted by the coal industry. The soil was sieved to $2 \mathrm{~mm}$ and then airdried before analysis. The soil was a loamy-sand with $12.4 \%$ clay, $33.2 \%$ silt, and $54.4 \%$ sand. The initial total concentration of 16 USEPA PAHs ( $\sum_{\text {PAHs }}$ ) was $69.7 \pm$ $2.2 \mathrm{mg} \mathrm{kg}^{-1}$ soil (on dry wt. basis). The initial carbon content of contaminated soil was $1.5 \pm 0.3 \%$ (grams per $100 \mathrm{~g}$ dry wt.).

\subsection{Mixture of wastes}

The mixture of wastes included leaves, branches, and bio-wastes consisting of green vegetables such as cabbage, spinach, and celery $(60 \%, 28 \%$, and $12 \%$ of total mixture on dry matter basis, respectively). All waste materials were crushed to $2 \mathrm{~mm}$ before mixing. The initial $\mathrm{C} / \mathrm{N}$ ratio of a composting mixture should range between 25 and 40 to provide suitable composting conditions. Therefore, the initial proportions in the waste mixture were calculated to get an initial $\mathrm{C} / \mathrm{N}$ ratio of 29.3 in the initial mixture.

The initial concentration of $\sum 16$ USEPA listed PAHs in the mixture of wastes was $5.0 \pm 0.2 \mathrm{mg} \mathrm{kg}^{-1}$ dry wt. The initial content of total carbon content in the mixture of

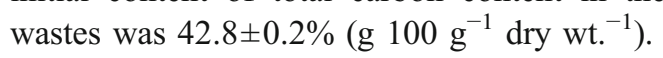

\subsection{Initial soil/waste mixtures}

The mixture of wastes was added to the contaminated soil with a ratio of $0.8: 1$ (dry wt. soil/dry wt. wastes) as used in Antizar-Ladislao et al. (2005). The TC content in the initial mixture was $24.5 \pm 0.7 \%$. The $\mathrm{C} / \mathrm{N}$ ratio of the initial soil/waste mixture was 25.6. The initial total concentration of 16 USEPA PAHs $\left(\sum_{\text {PAHs }}\right.$ ) was $75.95 \pm 2.4 \mathrm{mg} \mathrm{kg}^{-1}$ dry wt. of soil (33.75 mg kg${ }^{-1}$ dry wt. of mixture). The $\sum_{\mathrm{PAHs}}$ concentration 
was higher than that in contaminated soil because PAHs were also detected in the mixture of fresh wastes.

\subsection{Specific added microorganisms}

Bacillus sp., a Gram-positive rod-shaped bacterium, and Fusarium sp., a filamentous fungus widely distributed in soil and in association with plants, were isolated from the contaminated soil and cultured at $30^{\circ} \mathrm{C}$ and $175 \mathrm{rpm}$ in basal salt-glucose medium supplemented with pyrene (50 $\mathrm{mg} \mathrm{L}^{-1}$ ) before application to the soil-waste mixture of the SWB treatment. The population density was determined before inoculation using the dilution and spread plate method. The initial concentration of the two microbial populations (Bacillus sp. and Fusarium sp.) were $1 \times 10^{8}$ and $4.8 \times 10^{8}$ (colony forming units, $\mathrm{CFU} / \mathrm{ml}$ ), respectively.

Bacillus sp. was chosen because it represents a genus of bacteria that can survive during the thermophilic phase of composting. The Fusarium sp. offers other advantages: (1) most filamentous fungi are adapted to contaminated environments allowing the inoculum to survive and (2) Fusarium sp., preferentially degrades the high-molecularweight PAHs with 5- and 6-rings (Olivier et al. 2004).

\subsection{Bioreactors}

Beakers with a volume of $1 \mathrm{~L}$ (diameter of $106 \mathrm{~mm}$ and a height of $150 \mathrm{~mm}$ ) were used (see details in Fig. 1) and placed in water-bathes to control the temperature. Each treatment was run in triplicate in three separate beakers. During composting, the optimal aeration during the active phrase varied from $3 \mathrm{Lh}^{-1} \mathrm{~kg}^{-1}$ dry wt. (Lau et al. 1992; Sadaka and Taweel 2003) to $150 \mathrm{Lh}^{-1} \mathrm{~kg}^{-1}$ dry wt. (Mathur et al. 1993). The used aeration rate decreased during composting from $12-25 \mathrm{Lh}^{-1} \mathrm{~kg}^{-1}$ dry wt. at the beginning to $3-6 \mathrm{Lh}^{-1} \mathrm{~kg}^{-1}$ dry wt. at the end as proposed by Francou et al. (2008).

\subsection{Temperature and moisture}

The simulation of composting at a small scale is not obvious since the mass of biodegradable organic matter put into the reactors is not large enough to ensure a thermal inertia leading to thermophilic conditions and to maintain microbial activity over a long period. Bioreactors were placed in temperature-controlled water-bathes to simulate representative thermal stages during in-vessel composting processes. The variation temperature profile for the time periods days $0-14$ at $38^{\circ} \mathrm{C}$, days $15-35$ at $55^{\circ} \mathrm{C}$, days $36-$ 42 at $70^{\circ} \mathrm{C}$, and days $43-60$ at $38^{\circ} \mathrm{C}$ was chosen according to Antizar-Ladislao et al. (2005). These conditions simulated the operation of a commercial in-vessel operating system by including the minimum thermophilic temperature of $70^{\circ} \mathrm{C}$ required for pathogen control (Antizar et al. 2007). The optimal moisture content during composting generally varies between $50 \%$ and $80 \%$ of total wet mass (Willson 1989; Richard et al. 2002). The moisture content $(100 \times$ mass of water/mass of wet mixture) in treatments W, SW, and SWB were maintained to $50 \%$ by adding water into the bioreactors after each sampling event. In the control treatment $\mathrm{S}$, a moisture content of $50 \%$ made the contaminated soil too wet to be in aerobic condition, and a moisture content of $15 \%$ in treatment $\mathrm{S}$ was chosen within the maximum water content of soil. Li et al. (2006) also found that submerged conditions can inhibit the degradation of $\mathrm{B}[\mathrm{a}] \mathrm{P}$ in soil.

\subsection{Sample collection}

With the exception of the beginning and the end of composting (day 0 and 60), sampling occurred immediately prior to each change of temperature at days 14, 35, and 42. At every sampling date, the beakers were emptied, mixed thoroughly, and sub-sampled in triplicate. The sub-samples with about $20 \mathrm{~g}$ (wet weight) per sub-
Fig. 1 Design of bioreactor (volume of $1 \mathrm{~L}$ )

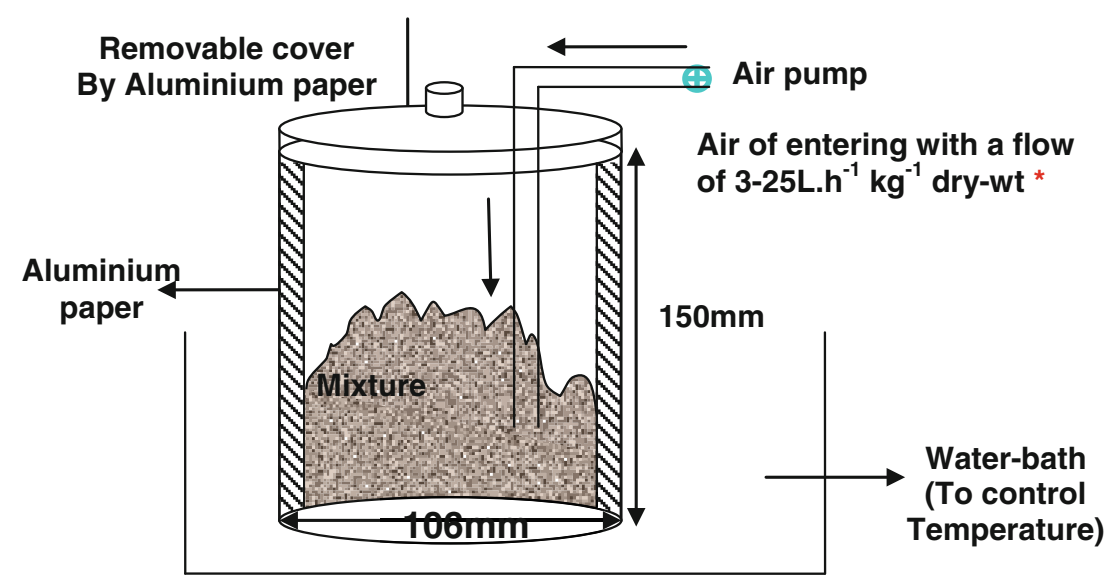


sample were frozen at $-80^{\circ} \mathrm{C}$ for the analysis of total organic matter (TOM), PAHs, phospholipid fatty acid (PLFA), and adsorption coefficient (Kd) of FLT and PHE on soil and on soil/waste mixture.

\subsection{Organic matter analysis}

The samples were dried in an oven at $105^{\circ} \mathrm{C}$ to obtain the dry weight. The evolution of biochemical fractions was measured using the Van Soest method (Van Soest and Wine 1967), but just for the treatment W because of the limits of the Van Soest method. Successive extractions of soluble in hot water $\left(\mathrm{H}_{2} \mathrm{O}\right)$, soluble substances in neutral detergent (SOL), hemicellulose-like (HEM), cellulose-like (CEL) and lignin and cutin-like (LIC) fractions were carried out as described in the French XPU 44-162 standard (AFNOR 2005).

\subsection{PAHs analysis}

The PAHs were extracted from $4 \mathrm{~g}$ samples which were dried by lyophilization and then weighed in triplicate into the pressure tubes used for accelerated solvent extractor (Dionex ASE-300). The solvent was a dichloromethane/ acetone (1:1) mixture. The sample and solvent were heated to $100^{\circ} \mathrm{C}$ and $10.35 \mathrm{MPa}$ pressure using the standard ASE program. The extracts were purified on chromatographic columns packed with $12 \mathrm{~cm} \mathrm{SiO}_{2}(100 / 200$ mesh; conditioned at $180^{\circ} \mathrm{C}$ during $12 \mathrm{~h}$ before use), $6 \mathrm{~cm} \mathrm{Al} \mathrm{O}_{3}(100 /$ 200 mesh; $250^{\circ} \mathrm{C} ; 12 \mathrm{~h}$ ), and $1 \mathrm{~cm} \mathrm{Na}_{2} \mathrm{SO}_{4}\left(450^{\circ} \mathrm{C} ; 4 \mathrm{~h}\right)$. In order to remove hydrophobic impurities, the columns were previously washed with $10 \mathrm{ml}$ hexane, then $5 \mathrm{ml}$ of extracts were eluted, and the columns were left to dry for $1 \mathrm{~min}$. The PAHs were then eluted with $70 \mathrm{ml}$ solvent (hexane: dichloromethane, $7: 3 v / v)$. The extracts were concentrated to $1 \mathrm{~mL}$ by flux of $\mathrm{N}_{2}$.

PAHs were analyzed using a GC-MS Chemstation (6890 N/5975 C, Agilent, USA) using a HP-5MS column (19091S-433, $30 \mathrm{~m} \times 0.25 \mathrm{~mm} \times 0.25 \mu \mathrm{m})$. The injection volume was $1 \mu \mathrm{L}$. The temperature program was $50^{\circ} \mathrm{C}$ for $2 \mathrm{~min}, 20^{\circ} \mathrm{C} \min ^{-1}$ to $200^{\circ} \mathrm{C}$, which was maintained for $2 \mathrm{~min}, 4.5^{\circ} \mathrm{C} \mathrm{min}^{-1}$ to $240^{\circ} \mathrm{C}$ which was maintained for $2 \mathrm{~min}$ and then $2.5^{\circ} \mathrm{C} \min ^{-1}$ to $290^{\circ} \mathrm{C}$. The MS was operated in selective ion monitoring (SIM) mode according to chemical ionization.

The 16 PAHs were grouped into three groups, according to the number of rings: small PAHs with 2- and 3-ring (naphthalene, acenaphthylene, acenaphthene, fluorine, anthracene); medium PAHs with 4-ring (fluoranthene, pyrene, benzo[a]anthracene, chrysene), and large PAHs with 5- and 6-ring (benzo[b]fluoranthene, benzo[k]fluoranthene, benzo [a]pyrene, ideno[1,2,3-c,d]pyrene, dipbenzo[a,h]anthracene, benzo[g,h,i]perylene).

\subsection{PAH sorption}

The sorption of PAHs was measured on fresh samples of the feedstock materials, the initial mixtures, the homogenized soil/waste mixture at each sampling event, and the initial contaminated soil. Two PAHs were used: fluoranthene (FLT) and phenanthrene (PHE). Average sample weight of soil/waste mixture was $1.0 \mathrm{~g}$ (soil) $/ 0.06 \mathrm{~g}$ (wastes) $\pm 0.003 \mathrm{~g}$ dry wt., $1.0 \mathrm{~g}$ dry wt. for waste, and $3.0 \pm 0.003 \mathrm{~g}$ dry wt. for the soil samples. Each measurement was done in triplicate. The equivalent PAH concentration in soil/waste mixture samples (expressed in milligram per kilogram dry wt.) was 1.95 and 1.98 for FLT and PHE. Volumes of 9,15 , or $15 \mathrm{ml}$ of ${ }^{14} \mathrm{C}-\mathrm{PAH}$ solution (methanol and alkaline solvents) prepared for the soil/waste mixture, wastes or soil sorption experiments, respectively, were added to the samples in glass corex tubes which were then shaken for $24 \mathrm{~h}$ at $20^{\circ} \mathrm{C}$ and then centrifuged for $10 \mathrm{~min}$ at $1,644 \mathrm{~g}$. The final concentration of ${ }^{14} \mathrm{C}-\mathrm{PAH}$ in the supernatants was determined by liquid scintillation counting (Tri-Carb 2100 TR, Perkin Elmer Ins., Courtabeuf, France) using Ultima Gold XR (Packard) as scintillation cocktail. The amount of ${ }^{14} \mathrm{C}$ PAH sorbed on the soil/waste mixture samples or soil sample $\left(Q_{\mathrm{s}}\right.$ in milligram per kilogram dry wt.) was calculated from the difference in concentration between the initial PAH solution and the corresponding centrifuged supernatant after $24 \mathrm{~h}$ of equilibration. The sorption coefficients $\mathrm{Kd}$ (in liters per kilogram dry wt.) were determined as $\mathrm{Kd}=Q_{\mathrm{s}} Q_{\mathrm{w}}{ }^{-1}$ where $Q_{\mathrm{w}}$ (in milligrams per liter) was the PAH concentration in supernatant solution after equilibration.

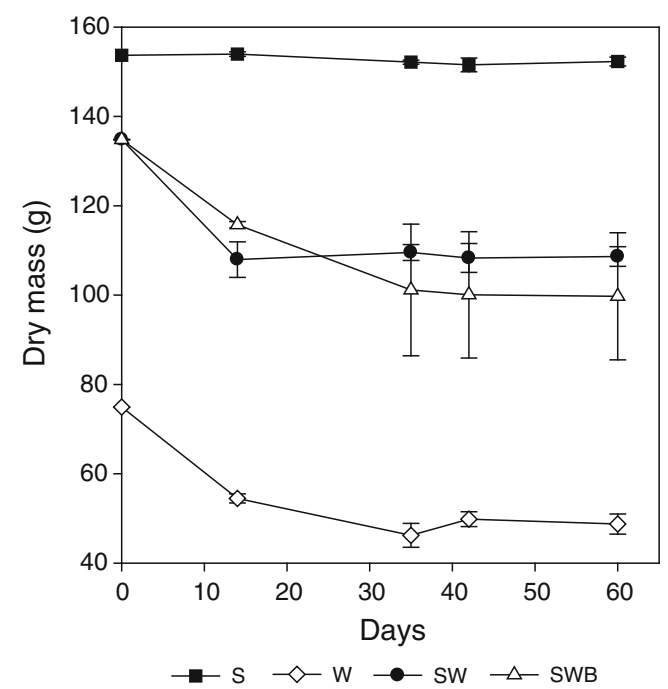

Fig. 2 Evolution of dry mass during composting for the different treatments (S, W, SW, and SWB) 
Fig. 3 Loss of carbon mass (Fig. 3a) and percentage of total initial organic carbon mineralization calculated according to the loss of carbon mass (Fig. 3b)

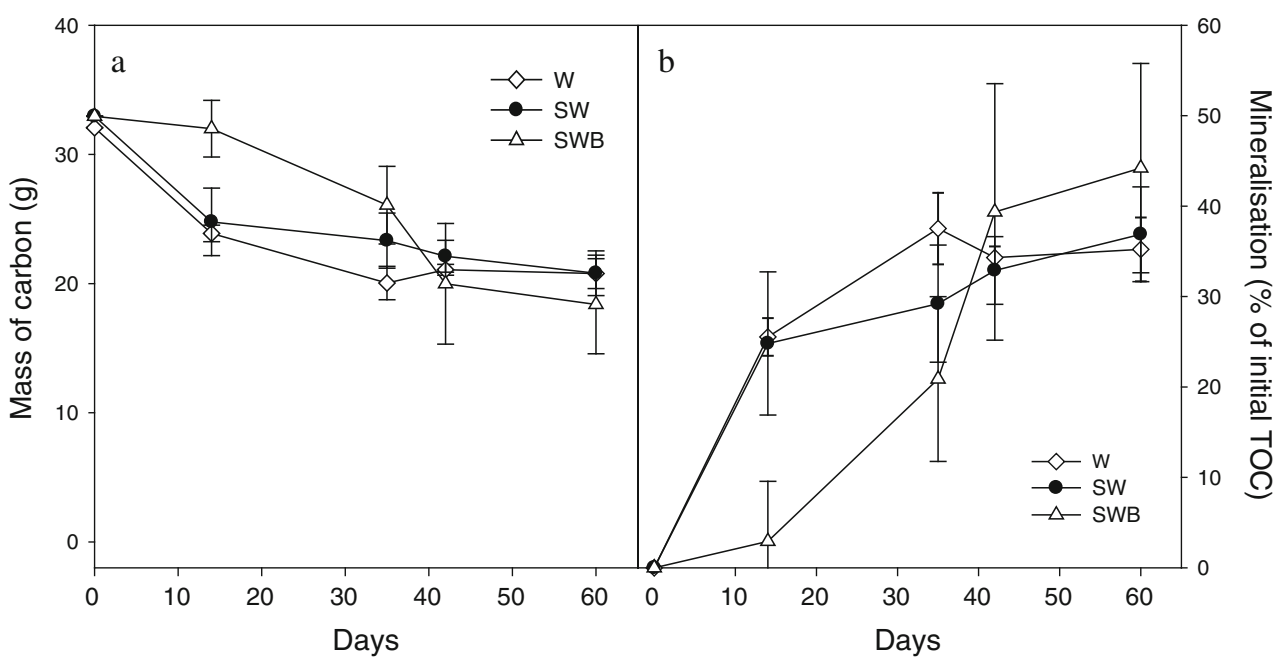

\subsection{PLFA analysis}

The lipids were extracted and stored under an atmosphere of $\mathrm{N}_{2}$. Soil and composting material lipids were extracted on $4 \mathrm{~g}$ samples in $30 \mathrm{ml}$ of chloroform/methanol/buffer $(1: 2: 0.8 v / v / v)$ by shaking for at least $2 \mathrm{~h}$ (biofilm) or overnight (soil and composting materials) at $21^{\circ} \mathrm{C}$. The chloroform phase was reduced by evaporation. Fatty acid methyl esters were quantified and identified by mass spectral comparison using a MS Chemstation (G1034C Version C.02.00) fitted with a HP-5MS column (19091S$433,30 \mathrm{~m} \times 0.25 \mathrm{~mm} \times 0.25 \mu \mathrm{m})$. The injection volume was $1 \mu \mathrm{L}$. The initial oven temperature was set at $120^{\circ} \mathrm{C}$ for $5 \mathrm{~min}$ and then increased at a rate of $20^{\circ} \mathrm{C} \mathrm{min}^{-1}$ to $180^{\circ} \mathrm{C}$ followed by a $4{ }^{\circ} \mathrm{C} \min ^{-1}$ increase to $240^{\circ} \mathrm{C}$. The MS was operated in selective ion monitoring (SIM) mode. Fatty acid nomenclature used was that described by Frostegård et al. (1993). Mono-unsaturated and cyclopropyl fatty acids were deemed to be Gram-negative bacterial $\left(\mathrm{G}^{-}\right)$ biomarkers (Zelles 1999), iso- and anteiso-fatty acids Gram-positive bacteria $\left(\mathrm{G}^{+}\right)$biomarkers (Zelles et al. 1995), C18:2(9,12), a fungal biomarker (Frostegård et al. 1993), and carboxylic acids with a methyl function on the carbon chain were treated as biomarkers of actinobacteria (Zelles and Bai 1994). The ratio of cyc-C17:0 to C16:1(7) cis, the trans-to-cis ratio, and the $i: a$ ratio were calculated as stress indicators (Navarrete et al. 2000). The ratio of fungal-PLFA to bacterial-PLFAs (as specified above) was
Fig. 4 Changes of the biochemical fractions during composting in the $\mathrm{W}$ treatment (100\% wastes) using the Van Soest method

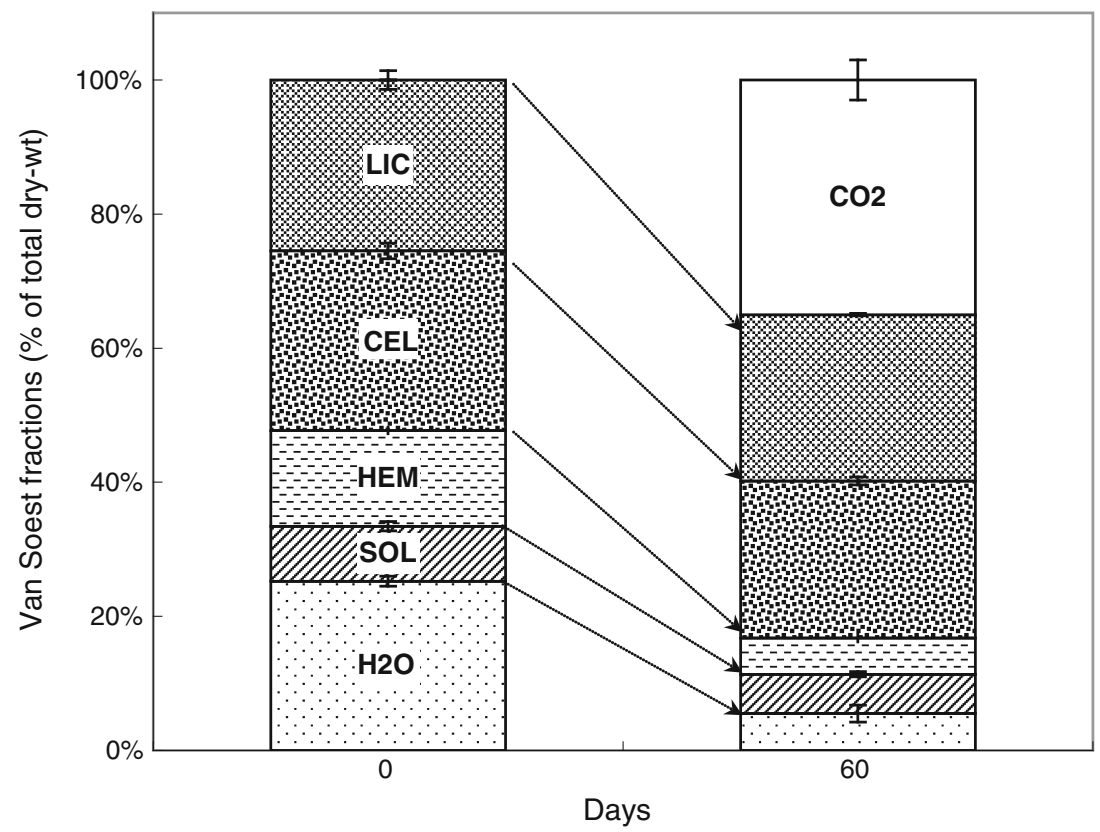




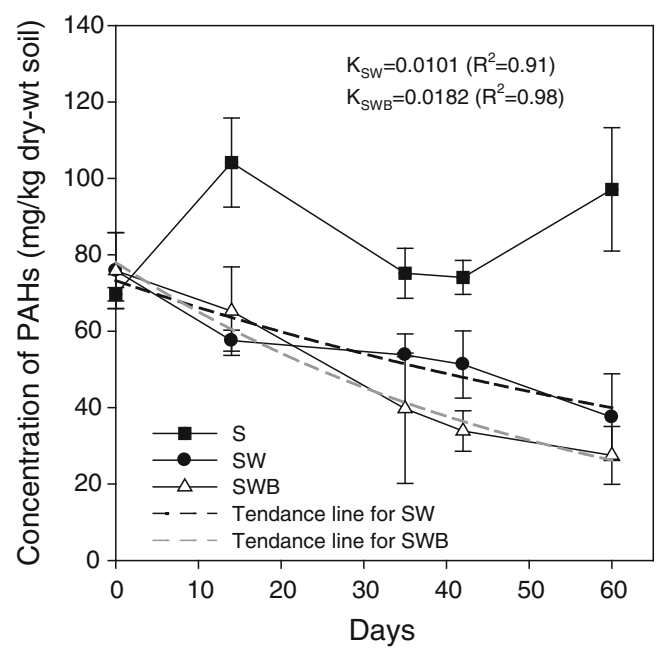

Fig. 5 Evolution of total PAHs during composting (mean \pm standard deviation) in the different treatments (S, W, SW, and SWB); first-order adjusted kinetics of dissipation in the SW and SWB treatments

used as an estimate of the relative importance of the bacterial and fungal energy channels (Parekh and Bardgett 2002). The fungal to bacterial PLFA and $\mathrm{G}+/ \mathrm{G}^{-}$bacterial ratios are considered as indicators of microbial community changes during in-vessel composting (Antizar-Ladislao et al. 2007).

\subsection{Statistical analysis}

Statistical procedures used to describe and evaluate the results were appropriate for the data of our study. The differences between treatments were tested by one-way analysis of variance using SAS (Version 8.1). The paired groups were evaluated using Burtlett's test. The comparison method Fisher's LSD with a significance level of 0.05 was used to test the significance of pairwise differences.

\section{Results and discussion}

\subsection{Dry mass}

The soil dry mass in treatment $\mathrm{S}$ remained constant during composting while dry mass losses were observed in the treatments W, SW, and SWB (Fig. 2). This occurred mainly during the first 14 days. A mean dry mass loss of $34.9 \pm$ $4.6 \%, 19.4 \pm 2.0 \%$, and $26.0 \pm 14.3 \%$ was found in treatments $\mathrm{W}, \mathrm{SW}$, and SWB, respectively, after 2 months of composting. The dry mass loss in treatment W $(34.9 \pm 4.6 \%)$ was close to that previously observed during the composting of other organic wastes (Sánchez-Monedero et al. 1999).

The mineralization of total carbon organic (TOC) into $\mathrm{CO}_{2}$ explained TOC loss which was calculated according to the dry mass loss during composting (Fig. 3a). The carbon loss represented $35.2 \pm 3.2 \%, 36.9 \pm 5.2 \%$, and $44.2 \pm 11.6 \%$ for treatments $\mathrm{W}, \mathrm{SW}$, and $\mathrm{SWB}$, respectively. The mineralization of TOC was calculated according to the carbon loss (see details in Fig. 3b). Significant differences were found between treatment W and SW/SWB $(P<0.05)$, while no significant differences could be found between treatments $(P>0.05)$. These results indicated that the influence of added degrading bacteria on the decomposition of organic matters was not noticeable.

\subsection{Organic matter analysis}

The evolution of Van Soest fractions of OM during the incubation is portrayed for the $\mathrm{W}$ treatment in Fig. 4. The

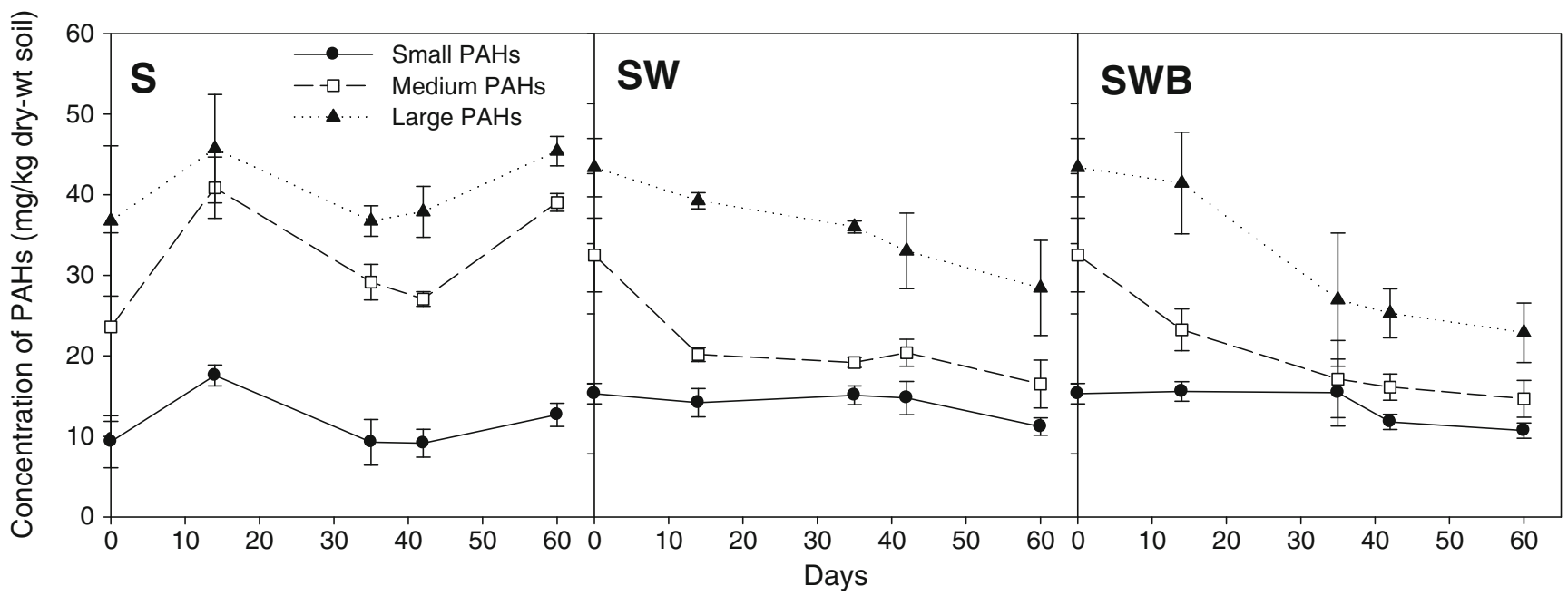

Fig. 6 Evolution of small (2- and 3-rings), medium (4-rings), and large (5- and 6-rings) PAHs concentrations in soil during composting 
Table 1 Small, medium, and large PAHs removal percentage for treatment SW and SWB

\begin{tabular}{lcccc}
\hline Treatment & \multicolumn{2}{l}{ PAHs removal (\%) } & & \\
\cline { 2 - 5 } & Small PAHs & Medium PAHs & Large PAHs & Total 16 USEPA PAHs \\
\hline SW & $55 \pm 14$ & $64.9 \pm 12.0$ & $42 \pm 17$ & $50.5 \pm 14.8$ \\
SWB & $61.3 \pm 12.7$ & $72.3 \pm 9.3$ & $57.7 \pm 10.4$ & $63.7 \pm 10.0$ \\
\hline
\end{tabular}
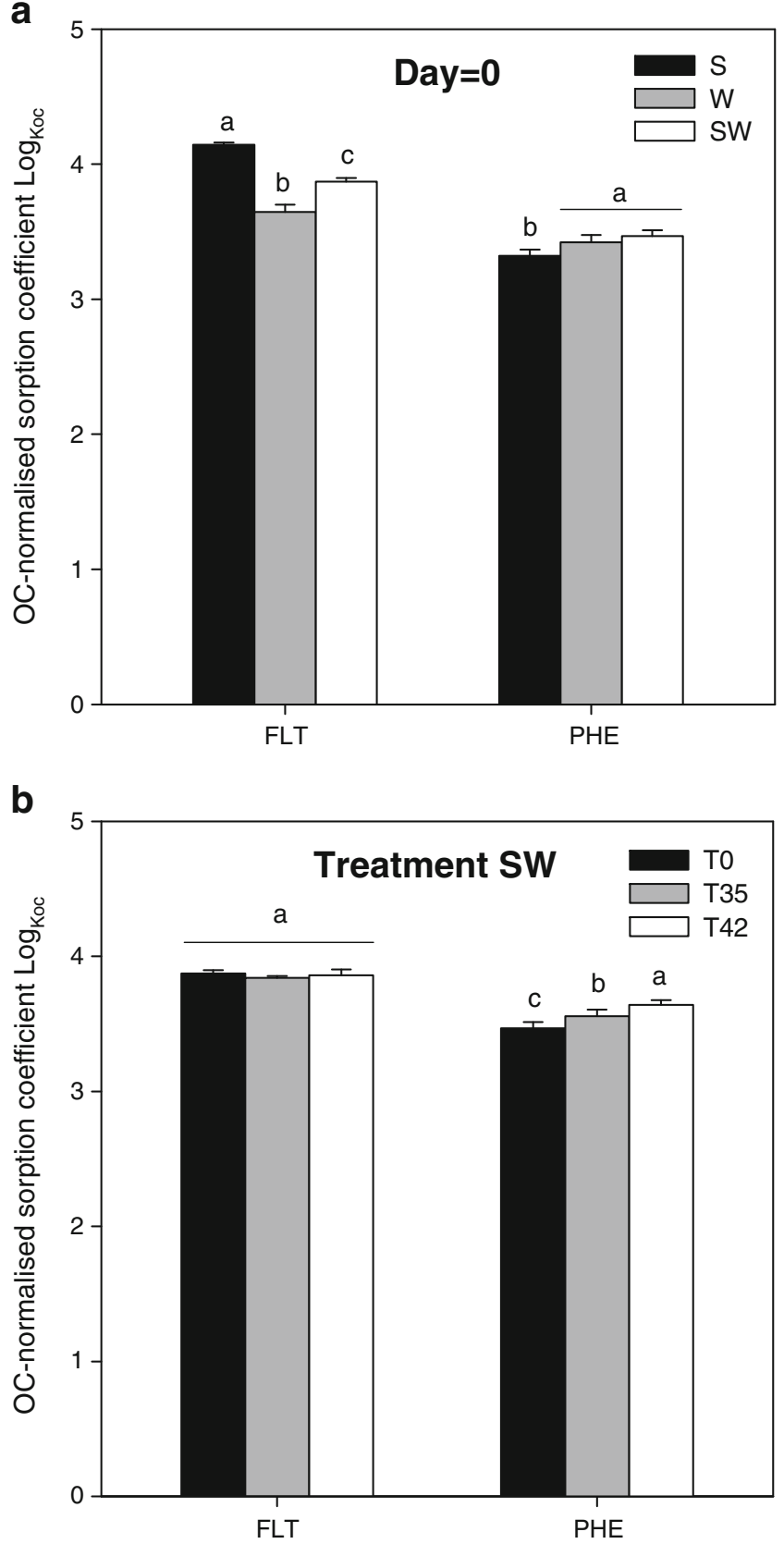

Fig. 7 a Organic carbon-normalized sorption coefficient of FLT and PHE in initial soil, waste, and soil-waste mixtures; b evolution of organic carbon-normalized sorption coefficient during composting in the soil-waste mixture (SW treatment). Different letters ( $a, b$, and $c$ ) within rows are significantly different $(P<0.05)$ according to one wayANOVA analysis mineralization fraction $\mathrm{CO}_{2}$ was calculated by using the dry mass balance, since the sum of all the organic fractions (SOL, $\mathrm{H}_{2} \mathrm{O}$, $\mathrm{HEM}, \mathrm{CEL}$, $\mathrm{LIC}$, and $\mathrm{CO}_{2}$ ) represented $100 \%$ of the initial total dry mass (see details in Fig. 4). The proportion of HEM and $\mathrm{H}_{2} \mathrm{O}$ fractions decreased while LIC, CEL, and SOL fractions remained constant. These results have generally been observed in other composting studies (Doublet et al. 2010; Francou et al. 2008) with the exception of the CEL fraction that generally decreases during composting. However, its degradation varies with the substrate of origin because of its spatial interaction with lignin (Doublet et al. 2010). The compost made from leafs may contribute to limit CEL degradation. The SOL fraction remained constant most likely because this pool was replenished by the decomposition of other organic matter pools at the same rate at which it was being degraded. The LIC fraction was always the most recalcitrant compartment for microbial degradation, and it changed least during the composting (Francou et al. 2008; Doublet et al. 2010). The $\mathrm{H}_{2} \mathrm{O}$ fraction, which represented the easily degradable compartment, contributed most to the dry mass loss (about $19.7 \%$ ). We assumed that the degradation of OM mixed with soil in SW and SWB treatments would follow a similar degradation pattern because at the end of the experiments, we found approximately the same amount of carbon lost (see Fig. 3).

\subsection{PAHs}

\subsubsection{Degradation of PAHs}

No significant degradation of PAHs was observed for treatment $\mathrm{S}$ during composting (Fig. 5), and the slight variations of concentrations observed were attributed to experimental variation of moisture content during the composting treatment that would potentially affect $\mathrm{PAH}$ concentrations (Antizar-Ladislao et al. 2005). The soil microflora was not able to degrade PAHs as observed by Kästner et al. (1999). On the other hand, total 16 USEPA PAH concentration decreased by $50.5 \pm 14.8 \%$ and $63.7 \pm$ $10.0 \%$ in treatments SW and SWB, respectively (Fig. 5), without significant difference between these two treatments $(P=0.564)$. The results indicated that degrading bacteria had no obvious effect on the PAH dissipation. This 
Fig. 8 Principal component analysis of PLFA data. PC1 and PC2 represents different dates of composting course. Principal component 1 (PC1) explained $68.1 \%$ of the variation, while PC2 explained $14.5 \%$. (Filled square) Experimental data of treatment $\mathrm{S}$; (filled circle) data of treatment W; (filled diamond): data of treatment SW; (filled triangle): data of treatment SWB. Different colors represented data with different date. Black $=$ day 0 ; deep gray $=$ day 14 ; gray $=$ day 35 ; black circle $=$ day 42 , and gray circle $=$ day 60

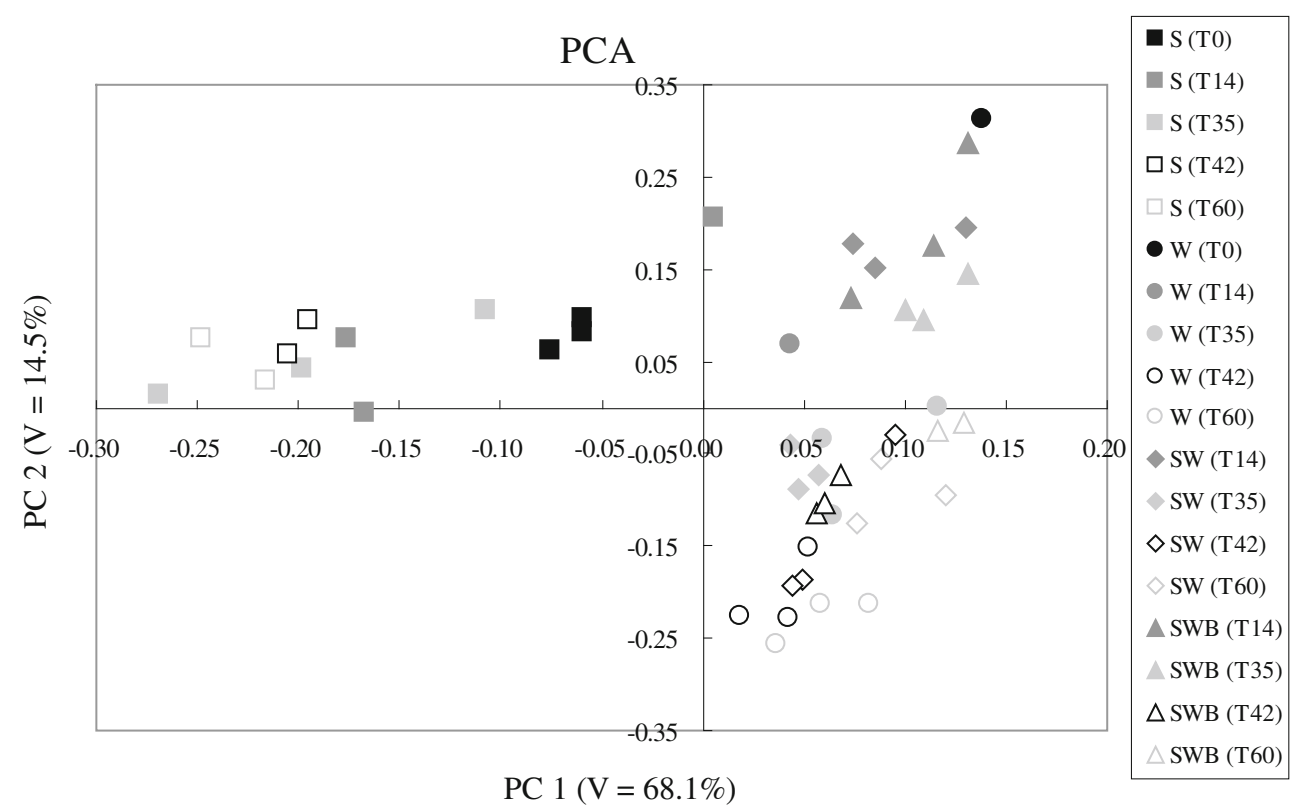

conclusion is supported by the research of Canet et al. (2001) who suggested that in soil amended by OM system, the use of the autochthonous microflora, with no introduction of foreign microorganisms, offered the greatest potential for PAH degradation. Other evidence has shown that in the experiments with soil from a contaminated site (Mahro et al. 1994), PAH degradation was most effectively stimulated after addition of compost in comparison to the addition of fertilizer or degrading bacteria.

First order kinetic equations were fitted to the kinetics of dissipation of PAHs, and the first order rate constants were 0.0102 day $^{-1}$ and 0.0176 day $^{-1}$ for treatments SW and SWB, respectively (Fig. 5), similar to the value $\left(0.0160\right.$ day $\left.^{-1}, R^{2}=0.93\right)$ reported in Antizar-Ladislao et al. (2007).

The amount and rate of PAHs dissipation varied according to their molecular weights (Fig. 6). Larger dissipation rates were observed for all PAHs in the SWB treatment compared to the SW treatment, but differences were not significant $(P>0.05)$. Detailed results of PAHs dissipation are shown in Table 1 . The highest dissipation was observed for medium PAHs in both treatments. This was particularly evident for four-ring PAHs, which are normally less reactive and biodegradable than lighter PAHs (Joner et al. 2004). Generally, large PAHs were more persistent than small and medium PAHs. Since large PAHs have higher octanol-water partition coefficients and lower water solubility than medium and small PAHs (AntizarLadislao et al. 2005), thus, bioavailability (Carriere and Mesania 1995; Potter et al. 1999; Lee et al. 2001) and toxicity (Sverdrup et al. 2002) may have limited their biodegradation, resulting in their persistence.

\subsubsection{Evolution of PAH sorption during composting}

In initial materials ( $\mathrm{S}, \mathrm{SW}$, or $\mathrm{W})$, the organic carbonnormalized sorption coefficient (expressed in $\log K_{\mathrm{OC}}$ ) ranged from 3.4 to 4.1 (liters per kilogram dry wt.) for both PAHs, which confirmed the strong sorption properties of these pollutants (Fig. 7a). These values were similar to the value (4.6-4.8) found by $\mathrm{He}$ et al. (1995) in soil. Significant differences in $\log K_{\mathrm{OC}}$ were observed for FLT between initial materials of $\mathrm{S}$ and the other initial materials of SW and $\mathrm{W}(P<0.05)$. We found a value of 4.1 for $\mathrm{S}$ treatment and 3.5-3.7 for W and SW treatments. Farenhorst (2006) found also that the $K_{\mathrm{OC}}$ of pesticide was higher in soil with humified organic matter compared to soil mixed with fresh organic matter. No significant difference could be found in PHE between treatments.

During composting of SW, no difference has been observed for $\log K_{\mathrm{OC}}$ of FLT, while for PHE, a slight increase of $\log K_{\mathrm{OC}}$ was noted over the time but without significant differences (Fig. 7b). These values of Log $K_{\mathrm{OC}}$ for SW were in agreement with the range from 4.4 to 4.9 found by Zhang et al. (2010) who investigated the $K_{\mathrm{OC}}$ values between PHE and biochar-amended soils. These results showed that the organic matter decomposition was not long enough to lead to noticeable changes of reactivity with these PAHs.

\subsection{PLFA profiling}

The implementation of composting technology as a remediation method requires an understanding of the diversity and ecology of contaminant-degrading micro- 
organisms. It is for this reason that changes within the microbial community structure were investigated by PLFA profiling to detect the major changes in microbial community structure during composting. The first two ordination axes, representing $83 \%$ of the total variability in the data, are presented in Fig. 8, where principal component (PC1) characterized the stages of composting. Contaminated soil samples were significantly $(P<0.05)$ separated from the waste samples and the soil and waste mixture samples along the first ordination axis. Inspection of the loadings

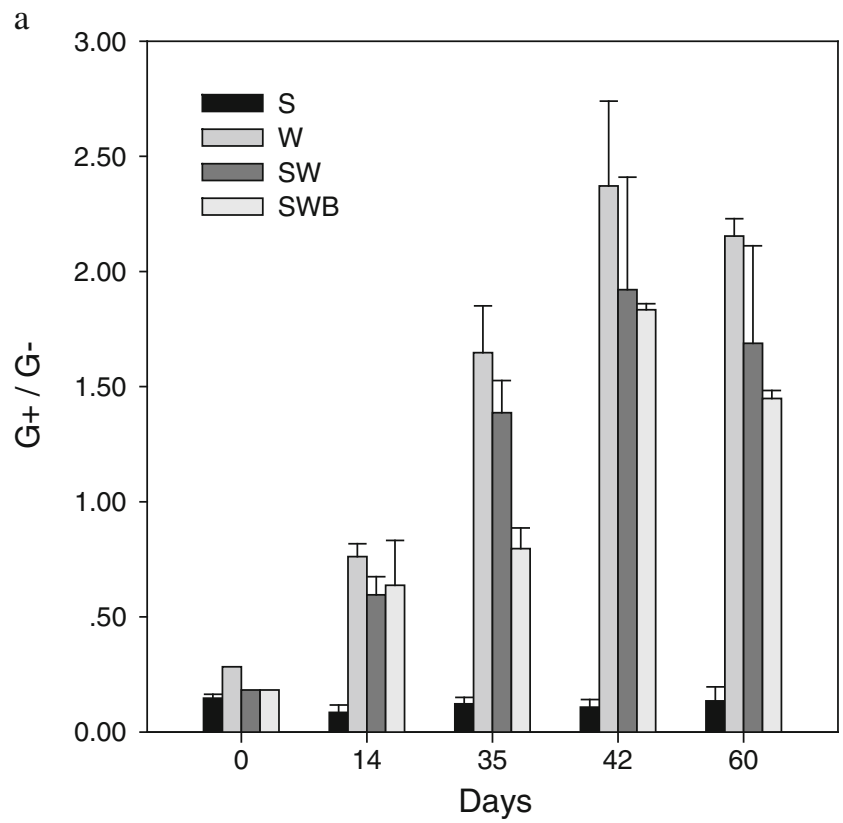

b

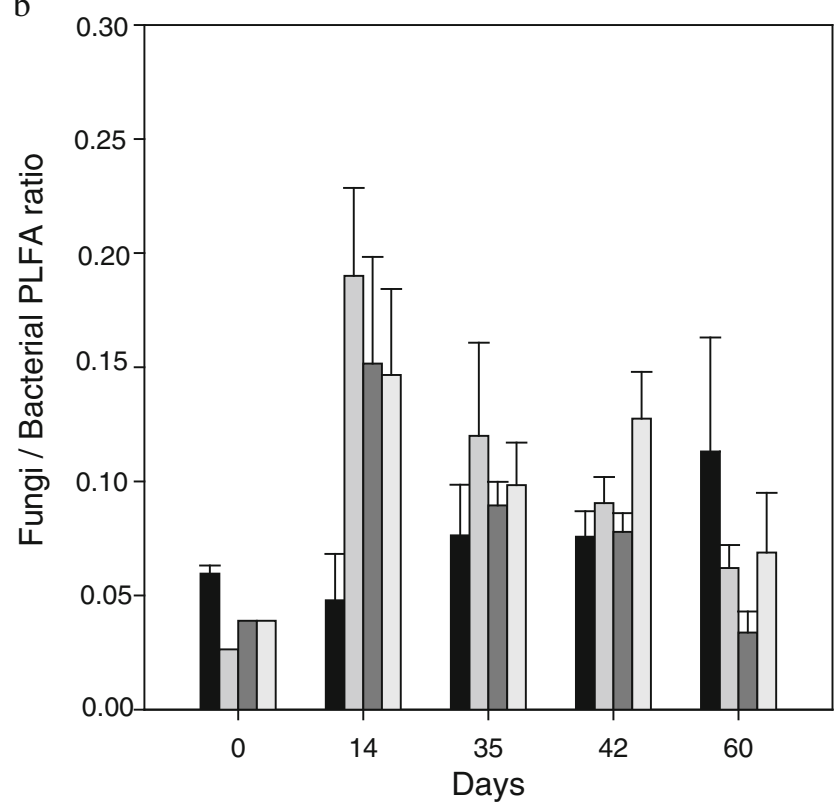

Fig. $9 \mathrm{G}+/ \mathrm{G}^{-}$(a) and fungal/bacterial PLFA ratio (b) in different treatments during composting process revealed that the difference between soil and other samples was primarily due to a higher relative abundance of fatty acids indicative of actinomycetes in the soil samples and higher relative abundance $\mathrm{G}+$ bacterial biomarkers in the other samples. No significant difference was observed between the waste samples and the soil-waste mixtures, suggesting that the waste microbial communities dominated in the soil-waste mixture. Microbial community structure also varied significantly $(P<0.05)$ with time in all treatments. Variation as a function of time was more pronounced in the contaminated soil than in the waste or soilwaste mixture, and it was apparent on the first ordination axis. It was due to an increase in the abundance of actinobacteria. The second ordination axis showed the variation as a function of time in the other treatments. The lipid profiles of these samples were initially dominated by $\mathrm{G}^{-}$bacterial and fungal biomarkers. As the incubation progressed, these treatments saw a distinct increase in the abundance of $\mathrm{G}+$ bacteria (see Fig. 9a). It has been suggested that the $\mathrm{G}+$ bacteria like actinomycete may play an important role in the mineralization of PAHs (Kästner et al. 1994; Larkin et al. 2005), and these are also thermophiles, meaning they are likely to be encountered at the higher temperatures (above $38^{\circ} \mathrm{C}$ ) used during the variable temperature profile. Thus, a higher relative proportion of $\mathrm{G}+$ was expected (Antizar-Ladislao et al. 2008).

According to Fig. 9b, the fungal to bacterial PLFA ratio was observed to be in the range of 0.03 to 0.19 which was within the range of $0.01-0.48$ found by Antizar-Ladislao et al. (2007). The fungal to bacterial PLFA ratio in treatments SW and SWB displayed a large degree of variation compared to treatment $\mathrm{S}$. The same trends with time were observed for both of these treatments with an increase of the ratio during the first 14 days and a steady decline thereafter. These results corroborate the results of AntizarLadislao et al. (2007), which indicated that an increase in temperature in the bioreactors from $38^{\circ} \mathrm{C}$ to $70^{\circ} \mathrm{C}$ reduced the fungal to bacterial PLFA ratio to low values.

\section{Conclusion}

In this study, the carbon loss was observed in all treatments W (100\% of wastes), SW (soil:wastes $=0.8: 1$ on dry wt.) and SWB (soil/wastes mixtures with a ratio of $0.8: 1$ and added by degrading microorganisms). The organic matter degradation occurred due to the decomposition of $\mathrm{H}_{2} \mathrm{O}$ (soluble organic matter in hot water) and HEM (hemicellulose-like) fractions during the composting. The soluble fraction $\mathrm{H}_{2} \mathrm{O}$ contributed most to the total organic matter loss. The composting of contaminated soil amended with fresh waste mixtures can reduce PAH concentrations within a 40th and 70th percentile range by a dissipation rate 
varying from 0.0101 to $0.0182 \mathrm{day}^{-1}$ for treatments SW and SWB after 60 days of continuous treatment following a variable temperature profile. No significant influence of degrading bacteria could be found on the dissipation of PAHs. The observation of microbial activity showed that these samples were initially dominated by $\mathrm{G}-$ bacterial and fungal biomarkers. Fungal biomarkers were particularly abundant during the first 14 days of composting when the PAHs dissipated most obviously. As was demonstrated by Canet et al. (1999), white-rot fungi have the potential to degrade PAH. These microorganisms naturally decompose lignin and cellulose inside wood fibers using a non-specific enzymatic complex, which also enables them to degrade a wide range of contaminants if they are introduced to soils. As the incubation progressed, these treatments showed a distinct increase in the abundance of $\mathrm{G}+$ bacteria. Thus, using fresh green wastes as composting amendment could achieve a higher dissipation of PAHs than in non-amended soil due the organic nutrients provided for microbial communities. However, the active microbial communities in each composting phase have not yet been quantified and qualified in this study, and more research in this direction might be beneficial. The bioremediation in contaminated soil by composting showed a complex system. Therefore, in future studies, we will focus on modeling these connected processes in order to answer the following questions: how the PAHs are affected by the composting process with and without foreign degraders; which are the dominant microbial populations responsible for the PAH dissipation during the composting.

Acknowledgements We are grateful to Egide, the French ministry of Foreign Affairs and the Chinese Academy of Sciences for providing financial support for this study through the programs PHC-PFCC and kzcx1-yw-06-03, respectively. We thank Nathalie Bernet and Valerie Dumeny for supplying the PAH measurements in contaminated soil and Muriel Jolly for her assistance in the organic matter analysis (Van Soest).

\section{References}

AFNOR (2005) Norme française NFU 44-162. Amendements organiques et supports de culture-Fractionnements biochimiques et estimation de la stabilité biologique. AFNOR, Paris

Alexander M (1999) Biodegradation and bioremediation, 2nd edn. Academic, San Diego, p 453

Amir S, Hafidi M, Merlina G, Hamdi H, Revel JC (2005) Fate of polycyclic aromatic hydrocarbons during lagooning sewage sludge. Chemosphere 58:449-458

Antizar-Ladislao B, Lopez-Real J, Beck AJ (2005) Laboratory studies of the remediation of polycyclic aromatic hydrocarbon contaminated soil by in-vessel composting. Waste Manage 25:281-289

Antizar-Ladislao B, Lopez-Real J, Beck AJ (2006) Degradation of polycyclic aromatic hydrocarbons (PAHs) in an aged coal-tar contaminated soil under in-vessel composting conditions. Environ Pollut 141:459-468
Antizar-Ladislao B, Beck AJ, Spanova K, Russell NJ, Lopez-Real J (2007) The influence of different temperature programmes on the bioremediation of polycyclic aromatic hydrocarbons (PAHs) in a coal-tar contaminated soil by in-vessel composting. J Hazard Mater 144:340-347

Antizar-Ladislao B, Spanova K, Beck AJ, Russell NJ (2008) Microbial community structure changes during bioremediation of PAHs in an aged coal-tar contaminated soil by in-vessel composting. Int Biodeterior Biodegradation 61:357-364

Atagana HI (2004) Co-composting of PAH-contaminated soil with poultry manure. Lett Appl Microbiol 39:163-168

Brändli RC, Bucheli TD, Kupper T, Furrer R, Stadelmann FX, Tarradellas J (2005) Persistent organic pollutants in sourceseparated compost and its feedstock materials - a review of field studies. J Environ Qual 34:735-760

Boonchan S, Britz ML, Stanley GA (2000) Degradation and mineralization of high molecular-weight polycyclic aromatic hydrocarbons by defined fungal-bacterial cocultures. Appl Environ Microbiol 66(3):1007-1019

Cai QY, Mo CH, Wu QT, Zeng QY, Katsoyiannis A, Ferard JF (2007) Bioremediation of polycyclic aromatic hydrocarbons (PAHs)contaminated sewage sludge by different composting processes. J Hazard Mater 142:535-542

Canet R, Lopez-Real J, Beck AJ (1999) Overview of polycyclic aromatic hydrocarbon biodegradation by white-rot fungi. Land Contam Reclamation 7:191-197

Canet R, Birnstingl JG, Malcolm DG, Lopez-Real JM, Beck AJ (2001) Biodegradation of polycyclic aromatic hydrocarbons (PAHs) by native microflora and combinations of white-rot fungi in a coal-tar contaminated soil. Bioresour Technol 76:113-117

Carmichael LM, Christman RF, Pfaender FK (1997) Desorption and mineralization kinetics of phenanthrene and chrysene in contaminated soils. Environ Sci Technol 31(1):126-132

Carriere PPE, Mesania FA (1995) Enhanced biodegradation of creosote-contaminated soil. Waste Manage 15:579-583

Doublet J, Francou C, Poitrenaud M, Houot S (2010) Sewage sludge composting: Influence of initial mixtures on organic matter evolution and $\mathrm{N}$ availability in the final composts. Waste Manage 30:1922-1930

Englert CJ, Kenzie EJ, Dragun J (1993) Bioremediation of petroleum products in soil. In: Calabrese EJ, Kostecki PT (eds) Principles and practices for petroleum contaminated soils, chap. 8. Lewis, Boca Raton

Farenhorst A (2006) Importance of soil organic matter fractions in soil-landscape and regional assessments of pesticide sorption and leaching in soil. Soil Sci Soc Am J 70(3):1005-1012

Francou C, Linères M, Derenne S, Le Villio-Poitrenaud M, Houot S (2008) Influence of green waste, biowaste and paper-cardboard initial ratios on organic matter transformations during composting. Bioresour Technol 99:8926-8934

Frostegård Å, Tunlid A, Bååth E (1993) Phospholipid fatty acid composition, biomass, and activity of microbial communities from two soil types experimentally exposed to different heavy metals. Appl Environ Microbiol 59(11):3605-3617

He YW, Yediler A, Sun T, Kettrup A (1995) Adsorption of fluoranthene on soil and lava: effects of the organic carbon contents of adsorbents and temperature. Chemosphere 30 (1):141-150

Joner EJ, Hirmann D, Szolar OHJ, Todorovic D, Leyval C, Loibner AP (2004) Priming effects on PAH degradation and ecotoxicity during a phytoremediation experiment. Environ Pollut 128 (3):429-435

Kästner M, Breuer-Jammali M, Mahro B (1994) Enumeration and characterization of the soil microflora from hydrocarboncontaminated soil sites able to mineralize polycyclic aromatic hydrocarbons. Appl Microbiol Biotechnol 41:267-273 
Kästner M, Mahro B (1996) Microbial degradation of polycyclic aromatic hydrocarbons in soils affected by the organic matrix of compost. Appl Microbiol Biotechnol 44:668-675

Kästner M, Streibich S, Beyrer M, Richnow HH, Fritsche W (1999) Formation of bound residues during microbial degradation of $\left[{ }^{14} \mathrm{C}\right]$ anthracene in soil. Appl Environ Microbiol 1999:18341842

Larkin MJ, Kulakov LA, Allen CCR (2005) Biodegradation and Rhodococus masters of catabolic versatility. Curr Option Biotechnol 16:282-290

Lau AK, Lo KV, Liao PH, Yu JC (1992) Aeration experiments for swine waste composting. Bioressource Technol 41:145-152

Lee PH, Ong SK, Golchin J, Nelson GLS (2001) Use of solvents to enhance PAH biodegradation of coal tar-contaminated soils. Water Res 35:3941-3949

Li H, Luo YM, Song J, Wu LH, Christie P (2006) Degradation of benzo[a]pyrene in an experimentally contaminated paddy soil by vetiver grass (Vetiveria zizanioides). Environ Geochem Health 28:183-188

Mahro B, Schaefer G, Kfistner M (1994) Pathways of microbial degradation of polycyclic aromatic hydrocarbons in soil. In: Hinchee AR, Leeson E, Semprini L, Ong SK (eds) Bioremediation of chlorinated and polycyclic aromatic hydrocarbons. Lewis, Boca Raton, pp 203-217

Mathur SP, Dinel H, Owen G, Schnitzer M, Dugan J (1993) Determination of compost biomaturity: 2. Optical-density of water extracts of compost as a reflexion of their maturity. Biol Agric Hortic 10:87-108

Navarrete A, Peacock A, Macnaughton SJ, Urmeneta J, Mas-Castellà J, White DC, Guerrero R (2000) Physiological status and community composition of microbial mats of the Ebro Delta, Spain, by signature lipid biomarkers. Microb Ecol 39:92-99

Olivier P, Rafin C, Reignie E (2004) Bioremediation of an aged polycyclic aromatic hydrocarbons (PAHs)-contaminated soil by filamentous fungi isolated from the soil. Int Biodeterior Biodegradation 54:45-52

Parekh NR, Bardgett RD (2002) The characterisation of microbial communities in environmental samples. In: Keith-Roach MJ, Livens FR (eds) Interactions of microorganisms with radionuclides. Elsevier Science Ltd., New York, pp 37-60

Pignatello JJ, Xing BS (1996) Mechanisms of slow sorption of organic chemicals to natural particles. Environ Sci Technol 30:1-11

Potter CL, Glaser JA, Chang LW, Meier JR, Dosany MA, Herrmann RF (1999) Degradation of polynuclear aromatic hydrocarbons under bench-scale compost conditions. Environ Sci Technol 33:1917-1925

Richard TL, Hamelers HVM, Veeken A, Silva T (2002) Moisture relationships in composting processes. Compost Sci Util 10:286-302

Sadaka S, El-Taweel A (2003) Effect of aeration and C:N ratio on household waste composting in Egypt. Compost Sci Util 11 (1):36-40
Sánchez-Monedero MA, Roig A, Cegarra J, Bernal MP (1999) Relationships between water-soluble carbohydrate and phenol fractions and the humification indices of different organic wastes during composting. Bioresour Technol 70:193-201

Sasek V, Bhatt M, Cajthaml T, Malachova K, Lednicka D (2003) Compost-mediated removal of polycyclic aromatic hydrocarbons from contaminated soil. Arc Environ Contam Toxicol 44:336342

Sims JL, Sims RC, Matthews JE (1990) Approach to bioremediation of contaminated soil. Hazard Waste Hazard Mater 7:117-149

Sverdrup LE, Nielsen T, Krogh PH (2002) Soil ecotoxicity of polycyclic aromatic hydrocarbons in relation to soil sorption, lipophilicity, and water solubility. Environ Sci Technol 36:24292435

Van Soest PJ, Wine RH (1967) Use of detergents in the analysis of fibrous feeds. VI. Determination of plant cell constituents. J official chemists 50:50-55

Volkering F, Breure AM, Sterkenburg A, Vanander JG (1992) Microbial degradation of polycyclic aromatic hydrocarbons: effect of substrate availability on bacterial growth kinetics. Appl Microbiol Biotechnol 36:548-552

Wischmann H, Steinhart H (1997) The formation of PAH oxidation products in soils and soil/compost mixtures. Chemosphere 35:1681-1689

Wilson SC, Jones KC (1993) Bioremediation of soil contaminated with polynuclear aromatic-hydrocarbons (PAHs) - a review. Environ Pollut 81:229-249

Willson GB (1989) Combining raw materials for composting. BioCycle 30:82-83

Yang H, Su YH, Zhu YG, Chen MM, Chen BD, Liu YX (2007) Influences of polycyclic aromatic hydrocarbons (PAHs) on soil microbial community composition with or without vegetation. J Environ Sci Health Part Tox Hazard Subst Environ Eng 42:65-72

Zelles L, Bai QY (1994) Fatty acid patterns of phospholipids and lipopolysaccharides in environmental samples. Chemosphere 28:391-411

Zelles L, Bai QY, Rackwitz R, Chadwick D, Beese F (1995) Determination of phospholipid- and lipopolysaccharidederived fatty acids as an estimate of microbial biomass and community structures in soils. Biol Fert Soil 19:115-123

Zelles L (1999) Fatty acid patterns of phospholipids and lipopolysaccharides in the characterisation of microbial communities in soil: a review. Biol Fertil Soils 29:111-129

Zhang HH, Lin K, Wang HL, Gan J (2010) Effect of Pinus radiata derived biochars on soil sorption and desorption of phenanthrene. Environ Pollut 158:2821-2825

Zhang WX, Bouwer EJ, Ball WP (1998) Bioavailability of hydrophobic organic contaminants: effects and implications of sorption-related mass transfer on bioremediation. Ground Water Monit Remediat 18(1):126-138 